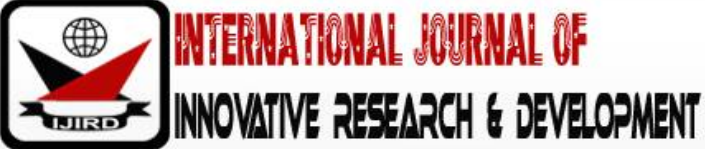

ISSN 2278 - 0211 (Online)

\section{Determination of Haematological Effects of Aqueous Leaf Extract of Cadaba Farinosa in Adult Wistar Rats}

\author{
Abdulrrahman A. Musa \\ Associate Professor, Department of Pharmacognosy, \\ Usman Danfodiyo University Sokoto, Nigeria \\ Abdulaziz Aisha \\ Laboratory Scientist, Department of Histopathology, \\ Usman Danfodiyo University, Nigeria \\ Kabir Hauwa \\ Head, Medical Laboratory Services, General Hospital \\ Yabo, Sokoto State, Nigeria \\ Abubakar Aliyu Khadijah \\ Head, Medical Laboratory Services, \\ General Hospital Bodinga, Sokoto State, Nigeria \\ Solomon Matthias Gamde \\ Head, Medical Laboratory Services, General Hospital \\ Silame, Sokoto State, Nigeria \\ Anthony Perede \\ Senior Scientist, Department of Haematology, \\ Specialist Hospital, Sokoto, Nigeria \\ Halilu E. Mshelia \\ Associate Professor, Department of Pharmacognosy \\ Usman Danfodiyo University, Nigeria
}

\begin{abstract}
:
Haematological parameters are frequently used to evaluate functional characteristics of blood and blood forming organs. Assessments of these parameters are not limited to established diagnosis of deleterious diseases nor prognosis, but also relating the blood functions of plant extracts. Plant extracts are alternative remedies in the managements of blood related disorders in developing countries including anaemia, neutropenia and thrombocytopenia. Anti-sickling property modelling entities that inhibit and reverse sequence of pathological processes leading to sickling was reported in Fagara zanthoxyloides, Khaya senegalensis and Garlic, possessing similar phytochemicals as Cadaba farinosa forsk is a rich natural source of alkaloids, flavonoids and terpenoids with antioxidant properties against oxidative damage. It's possess antithrombotic and vasoprotective properties. Bioflavonoids of Cadaba farinosa forsk demonstrated significant cytotoxicity against panel of cancerous cells. However, a possible haematological effect of Cadaba farinosa forsk is unevaluated. This study investigated effects of oral administration of aqueous leaf extracts of the plant. Twelve adult Wistar rats were divided into four groups of three rats $(n=30)$. Group 1served as negative control. Extract administered to groups (2, 3 and 4) following 28 days consecutively at dose levels 100, 200 and $300 \mathrm{mg} / \mathrm{kg}$, showed no significant change in RBC count compared with control group $(\mathrm{p}>0.05)$. PCV, PLT and HGB were not significant $(\mathrm{P}>0.05)$. However, there was significant elevation of WBC at $300 \mathrm{mg} / \mathrm{kg}(\mathrm{p}=0.02,4.28 \pm 2.38)(\mathrm{p}<0.05)$. Our finding also revealed statistically significant difference at 200 and $300 \mathrm{mg} / \mathrm{kg}$ of $\mathrm{MCHC}(304.50 \pm 3.54,303.00 \pm 5.66)$ compared to control $(\mathrm{P} \varangle 0.05)$. Hence, chronic toxicity studies are needed to further support the use of this plant for treatments.
\end{abstract}

Keywords: Haematological parameters, cadaba farinosa, leaf, aqueous extract, Wistar rats

\section{Introduction}

Haematological parameters(such as packed cell volume, platelet, neutrophils, lymphocytes, haemoglobin, mean corpuscular haemoglobin, mean corpuscular haemoglobin concentration, mean corpuscular volume, red blood cell count and white blood cell count) are frequently used to evaluatefunctional characteristicsof blood and blood forming organs $[1,2]$.Assessments of theseparametersare not limited to establisheddiagnosis of deleterious diseases norprognosis,but also relating the blood functions of plant extracts[3,4].Extracts of plant are alternative remediesinthe managements of blood 
related disorders including anaemia, neutropenia and thrombocytopenia than most conventional medicines in poor developing countries [5,6].The biochemical basis of herbal management of sickle has been reported [7]. Isomeric divanilloylquinic acids of Fagara zanthoxyloides root extract possess anti-sickling property modelling entities that inhibit or reverse the sequence of pathological processes leading to sickling was reported[8]. The anti-sickling effects of Garlic werealso documented [9] and Khaya senegalensis [10].

CadabafarinosaForskisa rich natural source of alkaloids, flavonoids and terpenoids [11]. Itsantioxidant properties against oxidative damage was scientifically investigated [12,13]. And it antithrombotic and vasoprotective properties were also reported [13]. The bioflavonoids of Cadabafarinosa demonstrated significant cytotoxicity against panel of cancerous cells [14].In Ayurvedic medicine,leaves of Cadabafarinosa is used to detoxify snake bite as well for fevers; a laxative to rid intestinal parasites and to treat diabetes [15].Our previous studies has shown that Cadabafarinosa induces the synthesis of prostaglandins whichpossess wide range of body functions including contraction and relaxation of smooth muscle and control of blood pressure [16]. This study was aimed at evaluating the possible haematological effects of aqueous leaf extract of Cadabafarinosaforskon normal adult Wistar rats as a preliminary step towards development of more efficacious plant-derived agent to manage haematological disorders and boost health.

\section{Materials and Method}

2.1. Study Site

This experiment was conducted at the Haematology Unit of Specialist Hospital Sokoto in conjunction with the Department of Medical Laboratory Science, Usman Danfodiyo University Sokoto.Sokoto State,Nigeria.

\subsection{Ethical Consideration}

The ethical approval for this research was obtained from Ethics Committee on Research and Experiment, Faculty of Pharmaceutical Sciences, Usmanu Danfodiyo University Sokoto, Nigeria.

\subsection{Experimental Animals}

Twelve (12) adult Wistar rats of both sexes, weight 180-200g were used for this study. The rats were housed in metal cages and maintained in 12 hour light and 12 hour dark regiment in an environment of normal ambient temperature. The ratswere fed ad libitum with standard commercial feed (Vital feed, Grand Cereals Nigeria PLC, Jos) and supplied with clean drinking water.

\subsection{Source of Plant Material}

The inner stem bark of Cadaba farinosa Forsk were harvested fresh at the Faculty of Pharmaceutical Science, Usmanu Danfodiyo University Sokoto, Sokoto state, Nigeria with a voucher number PCG/ UDUS/CAPP/ 0002. Phytochemical extraction was done at the Department of Pharmacognosy, Usmanu Danfodiyo University Sokoto. Sokoto State, Nigeria.

\subsection{Plant Extraction}

Fresh leaves of plant was harvested and shade-dried after which they were reduced into fine powder by grinding and soaked in distil water for 24 hours at room temperature. The mixture was filtered with Whatman No. 1 filter paper to to obtain particle free solution that was evaporated to dryness at $45^{\circ} \mathrm{C}$ in water bath [17]. The solid extract was then redissolved in distil water and stored in capped bottles in a refrigerator at $4^{\circ} \mathrm{C}$ until required.

\subsection{Experimental Design}

\begin{tabular}{|c|c|c|}
\hline $\begin{array}{c}\text { Groups of } \\
\text { Animals }\end{array}$ & $\begin{array}{c}\text { Daily Dose of Extract. } \\
\text { (mg/ kg body weight) }\end{array}$ & $\begin{array}{c}\text { Duration of } \\
\text { Administration(days) }\end{array}$ \\
\hline I & Distil water & 28 \\
\hline II & 100 & 28 \\
\hline III & 200 & 28 \\
\hline IV & 300 & 28 \\
\hline
\end{tabular}

.Table 1: Shows Experimental Animals and the Daily Doses of Extract Administered Consecutively for 28 Days $(\mathrm{n}=12)$

\subsection{Blood Collection for Analysis}

At the end of intervention, animals were sacrificed using chloroform. Blood was culled by cardiac puncture using $5 \mathrm{ml}$ sterile plastic syringes and needles from each animal aseptically; about $2.5 \mathrm{ml}$ of blood was poured into Ethylene Diamine Tetracetic Acid (EDTA) bottle that was mixed and kept at $4^{\circ} \mathrm{C}$ before haematological analysis on same day of collection.

\subsection{Haematological Investigations}

Thebloodcollected into EDTA anticoagulant bottles were subjected to complete blood cell count, platelets count and the red cell indices using the standard methods [18]. 


\subsection{Haemoglobin Estimation}

Whole blood was diluted 1 in 201 modify Drabkin's solution containing Potassium ferricyanide and Potassium cyanide. The red cells were haemolysed while haemoglobin was oxidized by ferricyanide to methaemoglobin which was converted to stable haemiglobincyanide $(\mathrm{HiCN})$ by the cyanide. Absorbance of the HiCN solution was read with a spectrophotometer at wavelength $540 \mathrm{~nm}$.

\subsubsection{Total Leukocyte Count}

Whole blood was diluted 1 in 20 in an acid reagent which haemolyses the red cells (not the nucleus of nucleated red cells) leaving the white cells to be counted.

\subsection{Erythrocyte Sedimentation Rate (ESR)}

Citrated blood in Westergreen's pipette was vertically positioned and left undisturbed. The red cells aggregates and stuck together (Rouleaux formation) and sediment through the plasma. ESR is the rate at which red cells sedimentation occurs in an hour, indicated by the length of the column of clear plasma above the red cell measured in $\mathrm{mm}$. High temperature (over $25^{\circ} \mathrm{C}$ ) increases red cells sedimentation.

\subsection{Platelet Count}

Blood was diluted 1:20 into filtered solution of Ammonium oxalate which lyses the red cells. Platelets are counted microscopically using Improved Neubauer Ruled Counting Chamber expressed as number of platelets per litre of blood.

\subsection{Differential White Cell Count (DWCC)}

DWCC provide vital information on different White Cells present in circulating blood (Neutrophils, Lymphocytes, Monocytes, Eosinophil and the rarely seen Basophils). Provided total WBC count is known, the absolute number of each White Cell type, the number of each cell per litre of blood is calculated to determine whether particular cell type is increased or decreased. Thin blood film was made on clean grease free glass slide and smears were stained using Leishman stain and viewed by oil immersion for different cell types.

\subsection{Statistical Analysis}

Data entry and validation was done using Microsoft excel version 13. SPSS 23.0 software was employed for analysis. Statistical analysis was carried out between the treatment group and control using multivariate analysis of variance (MANOVA). A multiple comparison test, least significant difference (LSD) was used to test for significant differences between control and the treatment means $\mathrm{p} \leq 0.05$ was considered statistically significant.

\section{Result}

The results showed that there was no significant change in RBC count of animals administered with extract compared to control group respectively $(\mathrm{p}>0.05$, Table 2$)$. The PCV PLT and HGB was not significantly higher $(P>0.05)$ than that of the control unlike WBC at $300 \mathrm{mg} / \mathrm{kg}$ ( $\mathrm{p}=0.02$, CI 1.350-10.500).

There was significant elevation of WBC at $300 \mathrm{mg} / \mathrm{kg}(4.28 \pm 2.38)(\mathrm{p}<0.05)$. However, there was no significant difference at 100 and $200 \mathrm{mg} / \mathrm{kg}$ compared to control. Furthermore, our finding also revealed statistical significant difference at 200 and $300 \mathrm{mg} / \mathrm{kg}$ of MCHC $(304.50 \pm 3.54,303.00 \pm 5.66)$ compared to control( $\mathrm{P}<0.05$, Table 4).

\begin{tabular}{|c|c|c|c|c|c|}
\hline Doses & $\begin{array}{c}\text { RBC } \\
(\times \mathbf{1 0 1 2} / \mathbf{L})\end{array}$ & $\begin{array}{c}\text { WBC } \\
\mathbf{\times 1 0 9} / \mathbf{L})\end{array}$ & PLT $(\times \mathbf{1 0 9} / \mathbf{L})$ & HGB (g/ dL) & HCT (\%) \\
\hline $100 \mathrm{mg} / \mathrm{kg}$ & $8.19 \pm 0.08$ & $12.98 \pm 0.75$ & $316.00 \pm 312.54$ & $12.60 \pm 0.00$ & $42.20 \pm 0.71$ \\
\hline $200 \mathrm{mg} / \mathrm{kg}$ & $9.48 \pm 2.60$ & $11.26 \pm 2.15$ & $655.00 \pm 22.63$ & $14.90 \pm 4.10$ & $48.90 \pm 13.01$ \\
\hline $300 \mathrm{mg} / \mathrm{kg}$ & $7.35 \pm 3.99$ & $4.28 \pm 2.38 *$ & $460.50 \pm 625.79$ & $11.00 \pm 5.37$ & $36.45 \pm 18.46$ \\
\hline Control & $9.39 \pm 0.84$ & $10.20 \pm 0.00$ & $571.00 \pm 96.17$ & $66.80 \pm 75.24$ & $39.10 \pm 11.60$ \\
\hline Total & $8.60 \pm 2.06$ & $9.68 \pm 3.71$ & $500.63 \pm 299.53$ & $26.33 \pm 37.97$ & $41.66 \pm 10.81$ \\
\hline
\end{tabular}

Table 2: Effects of Aqueous Leaf Extract of Cadaba farinosa following Oral Administration on Haematological Parameters of Wistar Rats and Their Normal Profile

All values are expressed as mean \pm SEM for 3 animals per group. Asterisk indicates significant difference between treated and control groups $(\mathrm{p}<0.05)$. 


\begin{tabular}{|c|c|c|c|c|c|c|}
\hline $\begin{array}{c}\text { WBC } \\
\times 109 / L)\end{array}$ & (J) Doses & $\begin{array}{l}\text { Mean Difference } \\
\text { (I-J) }\end{array}$ & $\begin{array}{l}\text { Std. } \\
\text { Error }\end{array}$ & Sig. & \multicolumn{2}{|c|}{ 95\% Confidence Interval } \\
\hline & & & & & Lower Bound & Upper Bound \\
\hline \multirow[t]{3}{*}{$100 \mathrm{mg} / \mathrm{kg}$} & $200 \mathrm{mg} / \mathrm{kg}$ & 1.720 & 1.648 & 0.356 & -2.855 & 6.295 \\
\hline & $300 \mathrm{mg} / \mathrm{kg}$ & $8.7050 *$ & 1.648 & 0.006 & 4.130 & 13.280 \\
\hline & Control & 2.780 & 1.648 & 0.167 & -1.795 & 7.355 \\
\hline \multirow[t]{3}{*}{$200 \mathrm{mg} / \mathrm{kg}$} & $100 \mathrm{mg} / \mathrm{kg}$ & -1.720 & 1.648 & 0.356 & -6.295 & 2.855 \\
\hline & $300 \mathrm{mg} / \mathrm{kg}$ & 6.9850* & 1.648 & 0.013 & 2.410 & 11.560 \\
\hline & Control & 1.060 & 1.648 & 0.555 & -3.515 & 5.635 \\
\hline \multirow[t]{3}{*}{$300 \mathrm{mg} / \mathrm{kg}$} & $100 \mathrm{mg} / \mathrm{kg}$ & $-8.7050 *$ & 1.648 & 0.006 & -13.280 & -4.130 \\
\hline & $200 \mathrm{mg} / \mathrm{kg}$ & $-6.9850 *$ & 1.648 & 0.013 & -11.560 & -2.410 \\
\hline & Control & $-5.9250 *$ & 1.648 & 0.023 & -10.500 & -1.350 \\
\hline \multirow[t]{3}{*}{ Control } & $100 \mathrm{mg} / \mathrm{kg}$ & -2.780 & 1.648 & 0.167 & -7.355 & 1.795 \\
\hline & $200 \mathrm{mg} / \mathrm{kg}$ & -1.060 & 1.648 & 0.555 & -5.635 & 3.515 \\
\hline & $300 \mathrm{mg} / \mathrm{kg}$ & 5.9250* & 1.648 & 0.023 & 1.350 & 10.500 \\
\hline
\end{tabular}

Table 3: A Multiple Comparison Test, Least Significant Difference (LSD) Within WBC

Following Oral Administration of Cadaba Farinosa on Haematological Parameters of Wistar Rats and Their Normal Profile

All values are expressed as mean \pm SEM for 3 animals per group. Values for each parameter are compared among animals administered with extract and negative control group for each dose by MANOVA and Least Significant Difference (LSD).*statistically significantly compared to control, $\mathrm{p}<0.05$.

\begin{tabular}{|c|c|c|c|c|c|}
\hline Group & WBC $\times \mathbf{1 0 9} / \mathbf{L})$ & PLT (×109/ L) & MCV (fL) & MCH (pg) & MCHC (g/ L) \\
\hline Control & $10.61 \pm 0.58$ & $669.50 \pm 43.13$ & $53.00 \pm 1.13$ & $15.45 \pm 0.07$ & $289.00 \pm 1.41$ \\
\hline $100 \mathrm{mg} / \mathrm{kg}$ & $12.98 \pm 0.75$ & $316.00 \pm 312.54$ & $51.50 \pm 1.41$ & $15.40 \pm 0.14$ & $298.50 \pm 4.95$ \\
\hline $200 \mathrm{mg} / \mathrm{kg}$ & $11.26 \pm 2.15$ & $655.00 \pm 22.63$ & $51.65 \pm 0.35$ & $15.75 \pm 0.07$ & $304.50 \pm 3.54^{*}$ \\
\hline $300 \mathrm{mg} / \mathrm{kg}$ & $4.28 \pm 2.38^{*}$ & $460.50 \pm 625.79$ & $50.20 \pm 2.26$ & $15.20 \pm 0.99$ & $303.00 \pm 5.66^{*}$ \\
\hline Total & $9.78 \pm 3.74$ & $525.25 \pm 307.74$ & $51.59 \pm 1.53$ & $15.45 \pm 0.43$ & $298.75 \pm 7.21$ \\
\hline
\end{tabular}

Table 4: Effects of Aqueous Extraction of Cadaba Farinosa on Haematological Parameters of Adult Albino Rats (N=12)

All values are expressed as mean \pm SEM for 3 animals per group. Asterisk indicates significant difference between treated and control groups $(\mathrm{p}<0.05)$.

\begin{tabular}{|c|c|c|c|c|c|c|}
\hline MCHC (g/ L) & (J) Doses & Mean Difference & Std. Error & Sig. & \multicolumn{2}{|c|}{ 95\% Confidence Interval } \\
\hline & & & & & Lower Bound & Upper Bound \\
\hline \multirow{3}{*}{$100 \mathrm{mg} / \mathrm{kg}$} & $200 \mathrm{mg} / \mathrm{kg}$ & -6.000 & 4.213 & 0.228 & -17.700 & 5.700 \\
\cline { 2 - 6 } & $300 \mathrm{mg} / \mathrm{kg}$ & -4.500 & 4.213 & 0.346 & -16.200 & 7.200 \\
\cline { 2 - 6 } & Control & 9.500 & 4.213 & 0.087 & -2.200 & 21.200 \\
\hline \multirow{3}{*}{$200 \mathrm{mg} / \mathrm{kg}$} & $100 \mathrm{mg} / \mathrm{kg}$ & 6.000 & 4.213 & 0.228 & -5.700 & 17.700 \\
\cline { 2 - 7 } & $300 \mathrm{mg} / \mathrm{kg}$ & 1.500 & 4.213 & 0.740 & -10.200 & 13.200 \\
\cline { 2 - 6 } & Control & $15.50 *$ & 4.213 & 0.021 & 3.800 & 27.200 \\
\hline \multirow{3}{*}{$300 \mathrm{mg} / \mathrm{kg}$} & $100 \mathrm{mg} / \mathrm{kg}$ & 4.500 & 4.213 & 0.346 & -7.200 & 16.200 \\
\cline { 2 - 6 } & $200 \mathrm{mg} / \mathrm{kg}$ & -1.500 & 4.213 & 0.740 & -13.200 & 10.200 \\
\cline { 2 - 6 } & Control & $14.00^{*}$ & 4.213 & 0.029 & 2.300 & 25.700 \\
\hline \multirow{3}{*}{ Control } & $100 \mathrm{mg} / \mathrm{kg}$ & -9.500 & 4.213 & 0.087 & -21.200 & 2.200 \\
\cline { 2 - 6 } & $200 \mathrm{mg} / \mathrm{kg}$ & $-15.50^{*}$ & 4.213 & 0.021 & -27.200 & -3.800 \\
\cline { 2 - 6 } & $300 \mathrm{mg} / \mathrm{kg}$ & $-14.00^{*}$ & 4.213 & 0.029 & -25.700 & -2.300 \\
\hline
\end{tabular}

Table 5: A Multiple Comparison Test, Least Significant Difference (LSD) Within MCHC

All values are expressed as mean \pm SEM for 3 animals per group. Values for each parameter are compared among animals administered with extract and negative control group for each dose by MANOVA and Least Significant Difference (LSD).*statistically significantly compared to control, $\mathrm{p} \varangle 0.05$.

\section{Discussion}

Normal functioning of the body of an organism requires that the blood composition and constituents are maintained under natural conditions [19]. A severe disorder has direct impact on blood parameters, so it is necessary to study the possible changes in haematological parameters [4]. Haematological evaluation in this study showed a significant increase in the level of white blood cell count $(\mathrm{p}<0.05)$ in rats administered with $300 \mathrm{mg} / \mathrm{kg}$ compared to normal control rats considering the $\mathrm{p}$-values (F-teats 30.347, $\mathrm{p}=0.01$ ) Roy s largest Root(Tables 1 and 2 ). However, this change does not occur in all hematological parameters. The significant increase in white blood cell and the differential leukocytes counts in the test animal shows that aqueous extracts of Cadaba farinosa Forsk may have immune boosting properties from the excitation of defence mechanism similar to those reported for Allum sativum [5], Channa punctatus [20] and Solanum 
incanum [19]. Since the extracts of Cadaba farinosa forskcaused increases in white blood cell counts, it is possible that the phytochemicals in the extract stimulated the production of these regulatory factors at the highest dose $(300 \mathrm{mg} / \mathrm{kg}) \mathrm{by}$ engaging the committed stem cells responsible for the production of white blood cells. The proliferations, differentiation and maturation of committed stem cells responsible for the production of white blood cells is regulated by granulocytemacrophage colony stimulating factor, macrophage colony stimulating factor, interleukins IL-2 IL-4 and IL-5 [19].

Further finding also revealed that there was statistical significant increase of MCHC at 200 and $300 \mathrm{mg} / \mathrm{kg}$ compared to the control group ( $\mathrm{P} \varangle 0.05$, Table 4).Decreased in MCHC (although significantly increased in this study), have been attributed to impairment of the biosynthesis of heme in bone marrow [21]. However erythrocytes, Platelet, Hemoglobin and HCT indices do not show statistical significant variation among the test group and control groups. The finding demonstrated that Cadabafarinosa does not cause any significant undesirable alteration on hematological factors of adult Wister rats.

\section{Conclusion}

Based on the aforementioned results, we concluded that oral administration of aqueous leaf extract of Cadabafarinosa significantly increases the white blood cell counts (WBC) and MCHC.

Theerythrocytes, haematocrit, haemoglobin and mean corpuscular volume were statistically insignificant. Hence, this underscores thatCadaba farinosaforskprob8ably stimulate immune defense mechanism.

\section{References}

i. Dorcas Bolanle James, Ene Blessing Adejor, Danladi Amodu Ameh, Adetoro Olubukola Kadejo, Taiye Olaba. (2014). Preventive and Therapeutic Effects of Garcinia kola Biflavonoid Fractions on some Haematological Parameters of P407 Induced Hyperlipidemic Albino Rats. Journal of Natural Remedies. 14(1):42-47.

ii. Firas Rashad Al-Samarai and Wathiq Ali Hasson Al-Jbory. (2017). Effect of some environmental factors on haematological parameters in apparently healthy Iraqi Awassi sheep. Journal of entomology and zoology Studies 2017; 5(3): 1668-1671.

iii. Yakubu, M., Akanji, A., Oladiji, A. (2007). Haematological Evaluation in Male Albino Rats Following Chronic Administration of Aqueous Extract of Fadogia agrestis Stem. Pharmacognosy Magazine, 3:34-38.

iv. Swati Shrivastava, Neelima Singh, Akshay Kumar Nigam, Sanjay Singh Chandel, Reetika Shrivastava1, Sarvesh Kumar. (2017). Comparative study of haematological parameters along with effect of chemotherapy and radiotherapy in different stages of breast cancer. International Journal of Research in Medical Sciences. 5(1):311-315.

v. Iranloye, B.O. (2002). Effect of Chronic Garlic Feeding on some Haematological Parameters. African Journal of biomedical Research.5:81-82.

vi. Njagi J Muriithi*, Gitahi S Maina, Njagi M Mugendi, Mwangi B Maina, Mworia J Kiambi, Juma K Kelvin, Aliyu Umar, Mwonjoria K John, Njoroge W Ann, Abdirahman YA, Ngugi M Piero and Njagi NM Eliud. (2015). Determination of Haematological Effects of Methanolic Leaf Extract of S. incanum in Normal Mice. Pharmaceutica Analytica Acta. 6(10):26.

vii. Sofowora, A. (1993). Medicinal and Traditional medicine in Africa. Second edition, Spectrum Books Limited, Ibadan, Nigeria. Pp. 130.

viii. Sofowora A. Medicinal plants and medicine in Africa. 3 rd edition. John Wiley Spectrum Books, Ibadan Nigeria. 2008; p 200-202

ix. Ohlsson A, Aher SM (2009) Early erythropoietin for preventing red blood cell transfusion in preterm and/ or low birth weight infants. Cochrane Database Syst Rev 6: 227-251.

x. A. B. Fall, R. Vanhaelen-Fastre, M. Vanhaelen et al., "In vitro ' antisickling activity of a rearranged limonoid isolated from Khaya senegalensis," Planta Medica, vol. 65, no. 3, pp. 209- 212, 1999.

xi. Siva N, Ganesan, Banumathy N,Muthuchelian. Antifungal effect of leaf extract of some Medicinal Plants against Fusariumoxysporum causing wilt disease of SolanummelogenaL.(Tamil Nadu, India) 2008: 1-8.

xii. Evans, C. Williams (2009).Trease and Evans Pharmacognosy, 6th Edition. China: Saunders Elsevier.

xiii. Haraguchi, H. (2001). Antioxidative Plant Constituents: Bioactive Compounds from Natural Sources. London: Taylor and Fracisinc. Pp 337- 379.

xiv. Silva, L. Gloria; I. K- Soo Lee and A. Douglas, Kinghorn. (1998). Special Problems with the Extraction of Plants, In: Cannell Corrado, (Ed.), Methods in Biotechnology, Natural Product Isolation. Totowa, New Jersey: Humana Press Inc.

xv. Umesh Telrandhe, Vaibhav Uplanchiwar (2013). Phyto-pharmacological Perspective of Cadaba farinosa forsk. American Journal of Phytomedicine and Clinical Therapeutics.1:011-022.

xvi. [16] Gamde S.M, Umar M, Avwioro O.G, Muhammad A.A. (2019). Effects of Aqueous Stem Bark Extract of Cadabafarinosa on the Gastrointestinal Tract of Wistar Rats. Annual General Meeting and Scientific Conference. Association of Specialist Doctors in Academic,Pp.18.

xvii. Majekodunmi O., Zany K., Olanyaga, I, Shi L and Melanhin J., (1996). Selective Toxicity Diterpene from Euphorbia Poi sonic. Journal of Medicinal Chemistry. 39:1005-1008.

xviii. Monica Cheesbrough (2006). District Laboratory Practice in Tropical Countries: Erythrocyte Sedimentation Rate. New York. Cambridge University press. $2^{\text {nd }}$ Edition.Pp.329-331.

xix. Njagi J Muriithi*, Gitahi S Maina, Njagi M Mugendi, Mwangi B Maina, Mworia J Kiambi, Juma K Kelvin, Aliyu Umar, Mwonjoria KJohn, Njoroge W Ann, Abdirahman YA, Ngugi M Piero and Njagi NM Eliud. Determination of Haematological Effects of Methanolic Leaf Extract of S. incanum in Normal Mice. Pharmaceutica Analytica Acta. 2015, 6:10;2-6.

xx. Jaya Shahi and Ajay Singh. Effect of Bioactive Compounds Extracted from Euphorbious Plants on Haematological and Biochemical Parameters of Channa punctatus. Rev. Inst. Med. Trop. Sao Paulo. 53(5):259-263.

xxi. Isselbacher, K. I., Braunwald, E., Wilson, J. D. (1992). Harrison's principle of internal medicine. New York McGraw-Hill. 